\title{
Efeito da mangiferina e do extrato das folhas de manga Ubá (Mangífera indica $L$ ) na modulação da expressão do Receptor PPARa e do Fator de Transcrição NFKB no tecido cerebral de animais induzidos à Síndrome Metabólica
}

\author{
Caetano, M. M. M.; Toledo, R. C. L.; Brito, L. F.; Queiroz, J. H. \\ Departamento de Bioquímica e Biologia Molecular, Universidade Federal de Viçosa, Viçosa/MG \\ *e-mail:monica.caetano@ufv.br
}

\section{Resumo}

A Síndrome Metabólica (SM) é vista atualmente como uma epidemia mundial, sendo a obesidade apontada como um dos seus principais fatores. Os PPARs (Peroxisome proliferator-activated receptors) possuem grande importância na regulação do metabolismo lipídico, na homeostase da glicose, na proliferação celular e apoptose. A distribuição da gordura corporal é um fator relevante e parece ser o elo entre o aumento de peso, a adipogênese, a inflamação e os riscos metabólicos. O extrato da folha de manga (Mangifera indica L) e a mangiferina possuem propriedades farmacológicas tais como antioxidante e anti-inflamatória, apresentando um potencial valor no tratamento da SM. O presente estudo teve como objetivo avaliar o efeito da mangiferina e do extrato das folhas de manga na expressão gênica do receptor PPAR $\alpha$ no cérebro de ratos alimentados com dieta de cafeteria. Ratos wistar receberam dieta comercial por 7 dias e após esse tempo receberam dieta de cafeteria e, por gavagem, o extrato das folhas de manga e a mangiferina isolada durante 7 dias. A ingestão alimentar e o peso corporal foram mensurados diariamente. Após eutanásia, o tecido cerebral foi removido e utilizado para verificar a expressão do receptor PPAR $\alpha$ pela técnica de RT-PCR (Reverse transcription polymerase chain reaction). Houve aumento da expressão do receptor PPAR $\alpha$ tanto no grupo que recebeu o extrato quanto no grupo que recebeu a mangiferina. $\mathrm{O}$ extrato não apresentou influência significativa sobre a expressão do $\mathrm{NF \kappa B}$, enquanto a mangiferina diminuiu a expressão do fator de transcrição. Conclui-se que o extrato das folhas de manga e a mangiferina modularam a expressão de genes associados aos 
fatores de risco metabólico, mostrando um alto potencial bioativo na adipogênese.

Palavras-chave: síndrome metabólica, Mangifera indica, mangiferina, receptor PPAR $\alpha, \mathrm{NF \kappa B}$.

Apoio financeiro: CNPq, CAPES, FAPEMIG. 